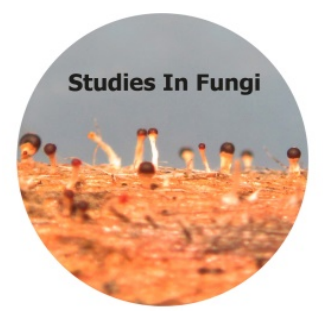

\title{
Boletellus nordestinus (Boletaceae, Boletales), a new species from Northeastern Atlantic Forest, Brazil
}

\author{
Magnago AC ${ }^{1}$, Neves $\mathrm{MA}^{2}$, Silveira $\mathrm{RMB}^{1}$
}

\begin{abstract}
${ }^{1}$ Programa de Pós-Graduação em Botânica, Departamento de Botânica, Universidade Federal do Rio Grande do Sul, Porto Alegre, Rio Grande do Sul, Brazil

${ }^{2}$ Programa de Pós-Graduação em Biologia de Fungos, Algas e Plantas, Departamento de Botânica, Universidade Federal de Santa Catarina, Florianópolis, Santa Catarina, Brazil
\end{abstract}

Magnago AC, Neves MA, Silveira RMB 2019 - Boletellus nordestinus (Boletaceae, Boletales), a new species from Northeastern Atlantic Forest, Brazil. Studies in Fungi 4(1), 54-60, Doi 10.5943/sif/4/1/8

\begin{abstract}
Boletellus nordestinus is described as a new species from white sandy dunes in the Northeastern Brazilian Atlantic Forest. The area is known as a potential ectotrophic forest, since some ectomycorrhizal fungi had been found in the same area. The new species is characterized by dry, velutinous and olivaceus to chocolate brown pileus, context and hymenophore non-cyanescent when exposed or pressured, short and longitudinally ridged basidiospores, fusiform to ventricose cystidia, and a trichodermal pileipellis with disarticulated, acute terminal elements. A full description, line drawings, color photographs and molecular phylogenetic data of the new species are provided.
\end{abstract}

Key words - Agaricomycetes - boletoid fungi - Neotropical fungi - taxonomy

\section{Introduction}

Boletellus Murrill (Boletaceae, Boletales, Basidiomycota) is a small group of ectomycorrhizal fungi forming mutualistic relationship with different host trees (Fulgenzi et al. 2008, Tedersoo et al. 2010). Morphologically the genus encompasses around 72 described species worldwide, the majority reported from tropical regions (Heinemann \& Goossens-Fontana 1954, Singer 1970, Snell \& Dick 1970, Smith \& Thiers 1971, Corner 1972, Horak 1977, Singer 1986, Singer et al. 1992, Gómez 1996, Watling 2001, Halling \& Mueller 2005, Ortiz-Santana et al. 2007, Fulgenzi et al. 2008, Halling \& Ortiz-Santana 2009, Halling et al. 2015, Sato \& Hattori 2015, Barbosa-Silva) Murrill (Murril 1909). According to authors, Boletellus has been variably defined, having in et al. 2017). The type species designated for the genus was the North American B. ananas (M.A. Curtis common: basidiospores olivaceous brown in deposit, yellow hymenophore becoming olivaceous with maturity and boletoid tube trama. Singer (1986) in the traditional morphological concept adhered a broad definition for Boletellus including seven sections based by the basidiospores ornamentation: smooth basidiospores (section Mirabilis); basidiospores with imbedded short spines or pits (section Allospori); reticulate basidiospores (section Retispori) and longitudinally winged or ridged basidiospores (sections Boletellus Murrill, Chrysenteroidei Singer, Ixocephali Singer and Dictyopodes Singer) using morphological characters of pileus and stipe to separate these sections. However, recent molecular phylogenetic studies indicate that such characters may not delimit 
clades in Boletaceae and Boletellus as morphologically circumscribed is polyphyletic (Dentinger et al. 2010, Nuhn et al. 2013, Wu et al. 2014, Halling et al. 2015). Boletellus s.str. may only include the two sections identified by Singer (1986), sect. Boletellus and sect. Chrysenteroidei Singer, with longitudinally winged or ridged basidiospores and a length/width ratio over two. Many species that were traditionally classified in Boletellus s.l., especially those without longitudinally winged or ridged basidiospores have been recently accommodated into new genera such as Aureoboletus Pouzar, Heimioporus E. Horak, and Hemileccinum Šutara.

For South America, few species are registered, and for Brazil only four Boletellus species are cited: B. ananas for the Amazon Forest (Singer et al. 1983), B. lepidospora E.-J. Gilbert ex Heinem., B. pustulatus (Beeli) E. J. Gilbert and B. cremeovelosus Barbosa-Silva \& Wartchow for the Atlantic Forest (Oliveira \& Sousa 1995, Barbosa-Silva \& Wartchow 2017). Here we describe $B$. nordestinus sp. nov. discovered in ectomycorrhizal white sandy dunes in the extreme north Atlantic Forest, as part of the project Diversity of boletoide fungi in the Brazilian native forests, where new species has been described recently (Magnago et al. 2014, Magnago et al. 2017a, 2017b, 2018a, 2018b). In the same area where the new species was found, other ectomycorryzal fungi (e.g. Amanita Pers., Coltricia Gray, Lactifluus (Pers.) Roussel, Russula Pers., Scleroderma Pers., Tylopilus P. Karst.) have been collected and described recently (Baltazar et al. 2010, Sá et al. 2013, Sulzbacher et al. 2013, Wartchow et al. 2013, Barbosa-Silva et al. 2017, Magnago et al. 2017b).

As part of our ongoing boletoid diversity surveys in the Brazilian Atlantic Forest, Boletellus nordestinus sp. nov. is described and proposed as new to science.

\section{Materials \& Methods}

\section{Sampling}

Collections were made in 2009 and 2016 in the Northeastern region of Brazil in the coastal Atlantic Forest, at "Reserva Biológica Guaribas", municipally of Mamanguape, Paraíba State and at "Parque Estadual Dunas de Natal", municipally of Natal, Rio Grande do Norte State. In both areas, the specimens were collected in white sandy soil. Macroscopic features were described from fresh basidiomata and dried with a food dehydrator (Total Chef TCFD-05 Deluxe) at about $40^{\circ} \mathrm{C}$. Color codes (e.g. OAC 640) were based on the Online Auction Color Chart (Kramer 2004). Macrochemical tests were performed according to Singer (1986). Microscopic structures were rehydrated in 3\% KOH and dyed with Congo Red (Largent et al. 1977). To observe the surface of the basidiospores in scanning electron microscopy (SEM), small fragments of the hymenophore were taken from dried specimens and mounted directly on aluminum stubs using carbon adhesive tabs, coated with $30 \mathrm{~nm}$ of gold, and examined with a JEOL JSM-6390LV scanning electron microscope, operating at $10 \mathrm{KeV}$, at the "Centro de Microscopia e Microanálise da Universidade Federal do Rio Grande do Sul”. All microscopic features were line drawings by hand using digital photographs from the specimens examined. Voucher materials were deposited at UFRN, FLOR and ICN (Thiers, continuously updated).

\section{Molecular data}

DNA was extracted from dried specimens followed Doyle \& Doyle (1987) protocol adapted by Góes-Neto et al. (2005). Nuclear ribosomal internal transcribed spacer nrITS (ITS1-5.8S-ITS2) and nuclear ribosomal large subunit (nrLSU) were PCR-amplified with primer pairs ITS6-R/ITS8F (Dentinger et al. 2010) and LR0R/LR7 (Vilgalys \& Hester 1990) respectively. Complementary unidirectional sequence reads were aligned and edited in Geneious 6.1.8 (Kearse et al. 2012) and deposited in GenBank with accession numbers listed in materials examined.

\section{Results}

Boletellus nordestinus A.C. Magnago, sp. nov.

Figs $1-2$ MycoBank number: MB823951 
Etymology - In homage to the Northeastern region ("Nordeste” in Portuguese) where the specimens were collected.

Diagnosis - Differs from the other Boletellus non-cyanescent species with the combination of dry, velutinous, chocolate brown pileus, short basidiospores, pleurocystidia and cheilocystidia fusiform to ventricose, and pileipellis trichodermal with acute terminal elements.

Holotypus - Brazil, Rio Grande do Norte, Natal, Parque Estadual das Dunas de Natal, 550'40"S, 35¹1'25,2"W, Trilha da Perobinha, 08 June 2016, Fazolino, E.P. \& Assis, N.M. s/n (UFRN-Fungos 2726), GenBank accessions: ITS = MG760443, nrLSU = MG760444).

Description - Pileus 38-66 mm wide, parabolic at first to convex when mature, velutinous to slightly fibrillose towards the margin, olivaceous to chocolate brown $(\mathrm{OAC} 733,735)$, dry; margin slightly uplifted when mature; context whitish to cream yellow (OAC 812), solid, unchanging when exposed. Hymenophore tubular, depressed around stipe, with decurrent tooth, tubes 5-8 mm long centrally, bright yellow (OAC 854, 895) when young maturing to olive yellow (OAC 10, 19), pores concolorours with tubes, not bluing under pressure, mostly 1-2 mm wide, subangular. Stipe 28-47 $\mathrm{mm} \times 5-8 \mathrm{~mm}$ central to eccentric, equal, surface longitudinally slightly rugulose with short squamules, light yellow to pinkish (OAC 12,14), some specimens more brownish to vinaceous brown (OAC 636, 638), context solid, fibrillose, cream yellow (OAC 812) near the apex becoming vinaceous brown downwards (OAC 638), unchanging when exposed, basal mycelium white. Basidiospores olivaceous-brown to dark olive-green (OAC 866, 867) in deposit, (7.5) 8-10 (11) $\times$ 6-7 (8) $\mu \mathrm{m} \quad(\mathrm{Qm}=1.40)$, broadly ellipsoid, longitudinally ridged, dichotomously forked, occasionally non-forked, terminating in unequal lengths near apex, ridges converging at hilar appendage, pale yellow, inamyloid, thick-walled, hilar appendage $0.5-1 \mu \mathrm{m}$ long. Basidia $27-42 \times$ 12-14 $\mu \mathrm{m}$, clavate, thin-walled, hyaline, inamyloid; 4-sterigmate, 2-3 $\mu \mathrm{m}$ long. Pleurocystidia and cheilocystidia not differentiated from each, 36-56 × 7-12 $\mu \mathrm{m}$, fusiform to ventricose, hyaline, inamyloid. Hymenophoral trama boletoid, hyphae 4-12 $\mu \mathrm{m}$ wide, hyaline, inamyloid, smooth and thin-walled. Pileipellis trichodermal, hyphae disarticulated, terminal hyphae acute, brownish, inamyloid, terminal hyphae $8-15 \mu \mathrm{m}$ wide; oileferous hyphae present. Pileus tramainterwoven, hyphae 6-16 $\mu \mathrm{m}$ wide, light yellow. Stipitipellis repent, with projecting tufts of caulobasidia and caulocistidia, clavate, fusiform to sphaeropedunculate, 28-38 x 13-15 $\mu \mathrm{m}$, hyaline, inamyloid. Stipe trama parallel to subparallel, hyphae 5-12 $\mu \mathrm{m}$ wide, light yellow, inamyloid. Clamp connections absent.

Habitat - Solitary to scattered, growing on white sandy soil and dunes in restinga vegetation in the far north of coastal Atlantic Forest. The vegetation is dominated by species of Leguminosae, Myrtaceae, Poaceae, Asteraceae and Euphorbiaceae (Freire 1990).

Geographic distribution - Known from Northeastern Brazilian region in the states of Paraíba and Rio Grande do Norte.

Material examined (paratypes) - Brazil, Paraíba, Mamanguape, Reserva Biológica Guaribas, SEMA II, 644'14"S, 358'55"W, 15 August 2009, coll. Neves M.A. MAN481 (FLOR51603); 23 September 2009, coll. Neves, M.A., Barbosa, M.R.V. \& Thomas, W. MAN502 (FLOR51604); Rio Grande do Norte, Natal, Parque Estadual das Dunas de Natal, 550'40"S, 35¹1'25,2"W, Trilha da Geologia, 07 June 2016, coll. Fazolino, E.P. \& Neto, J. F. F. s/n (UFRN-Fungos 2725) GenBank accessions: ITS = MG760442; 550'39"S, 35¹1'25,4' Trilha da Perobinha, 08 June 2016, coll. Fazolino, E.P \& Assis, N.M. s/n (UFRN-Fungos 2729).

Molecular data - Three new sequences of $B$. nordestinus sp. nov. were generated (two nrITS and one nrLSU). ITS and nrLSU BLASTn queries of the new taxon on GenBank indicated affinities with specimens in the genera Boletellus.

\section{Discussion}

Boletellus nordestinus is best disposed infragenerically in Boletellus section Chrysenteroidei Singer based on the longitudinally winged spore, perpendicular striations absent, pileus lacking red colors, veil absent, pileus and stipe not glutinous or viscid, stipe not lacunose-alveolate and clamp connections absent (Singer 1986). Boletellus fibuliger Singer from Venezuela has pileus brownish 


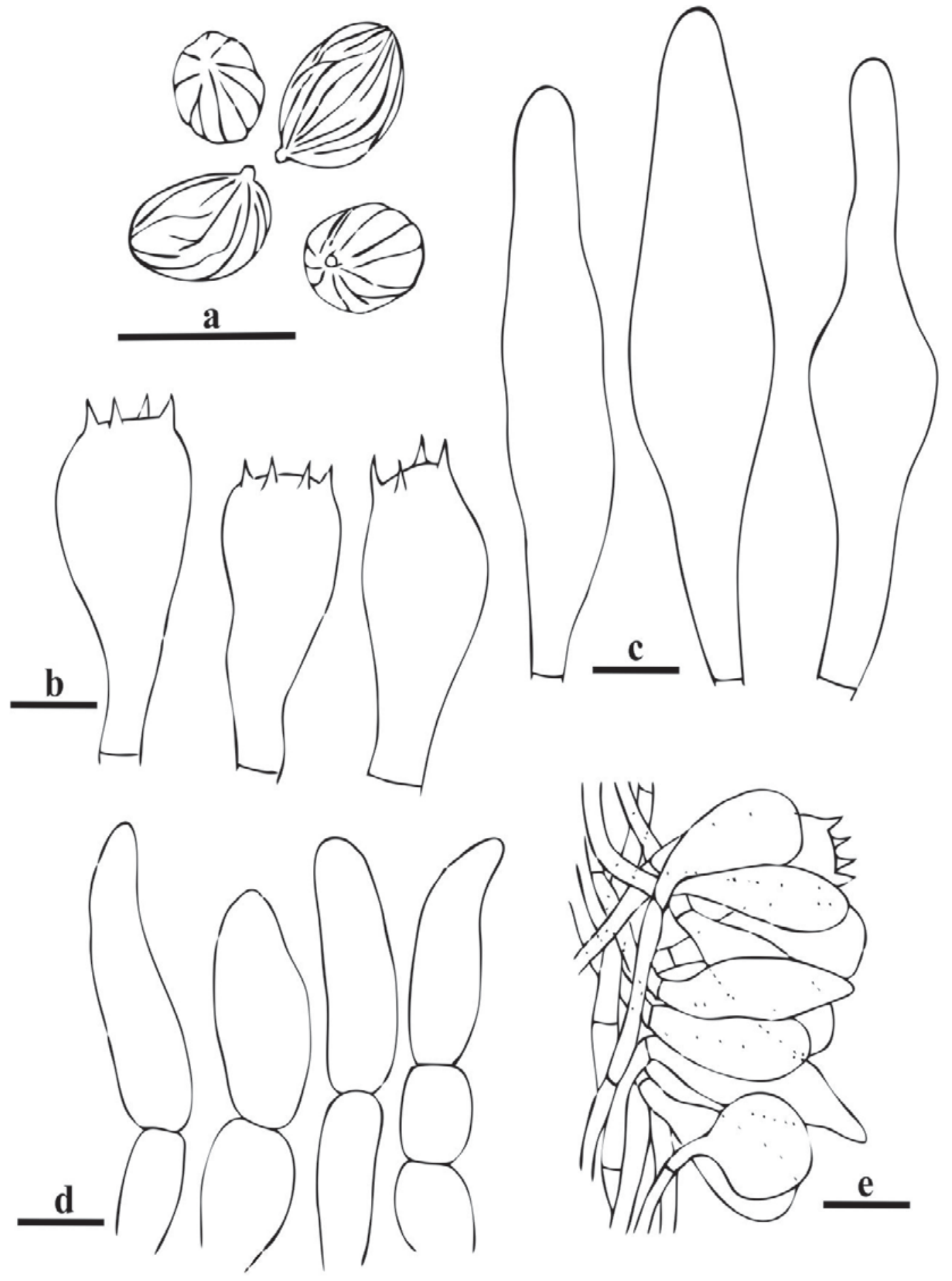

Fig. 1 - Micromorphology of Boletellus nordestinus (UFRN-Fungos 2726, holotype). a Basidiospores. b Basidia. c Cystidia. d Terminal cells of pileipellis from the pileus center. e Stipitipellis, cluster of caulobasidia and caulocystidia. Scale Bars: $10 \mu \mathrm{m}$.

fibrillose over a yellowish ground, less fibrillose towards the margin, not or scarcely appendiculate margin, larger basidiospores $(17-20 \times 9.5-11 \mu \mathrm{m})$, cystidia ampullaceous, and clamp connections present. Boletellus cubensis (Berk. \& M.A. Curt.) Singer from the eastern Caribbean, has squamulose pileus, red annular band on the stipe apex, bluing hymenophore when bruised, and the basidiospores are larger $(20-22.5 \times 7.5-10 \mu \mathrm{m})$. Boletellus chrysenteroides (Snell) Snell registered from Canada, USA and Honduras has larger basidiospores $(9.5-18.2 \times 5.3-9.8 \mu \mathrm{m})$ longitudinally ridged or winged, which are intervenose or themselves transversely striate, and is usually found 
growing under conifers. Boletellus exiguus T.W. Henkel and Fulgenzi from Guyana differs by the velutinous, finely squamulose and areolate pileus when mature, margin slightly inrolled when young, context and hymenophore bluing rapidly with exposure or pressure; pleurocystidia with golden incrustations in Melzer's, and a pileipellis of angular cells with tufts of erect inflated terminal elements (Fulgenzi et al. 2008). Boletellus dicymbophilus Fulgenzi and T.W. Henkel from Guyana has red-brown to yellow-tan, rugulose to rugose pileus, hymenophore instantly bluing on exposure or pressure, and larger basidiospores $(12-15 \times 8-11 \mu \mathrm{m})$ (Fulgenzi et al. 2008). Among the two Congolian Boletellus spp. cited by Oliveira \& Sousa (1995) for Atlantic Forest, Brazil, $B$. pustulatus possesses ventricose-rostrate cystidia and a bluing reaction in the exposed context (Gilbert 1931) and B. lepidospora has a rugulose brown to blackish pileus, stipe hollow towards the base, context yellow to light brown that becomes blue when exposed, basidiospores 11-12.5 $\times$ 6-7.4 $\mu \mathrm{m}$, cystidia lanceolate $(45-53 \times 12-13 \mu \mathrm{m})$ and pileipellis composed by subglobose terminal elements (Heinemann \& Goossens-Fontana 1954). These two last species cited for the Atlantic Forest should be recollected in the area to confirm its identification, because in the description of the Brazilian species by Oliveira \& Sousa (1995) the context when exposed are noncyanescent, and this is an important character of both species cited by Gilbert (1931) and Heinemann \& Goossens-Fontana (1954). Boletellus cremeovelosus differs by the beige and squamose pileus, margin strongly appendiculate, context and hymenophore bluing when exposed and pressured, and subfusoid, longitudinally ribbed (15.8-20.4 × 6.6-9.2) basidiospores.
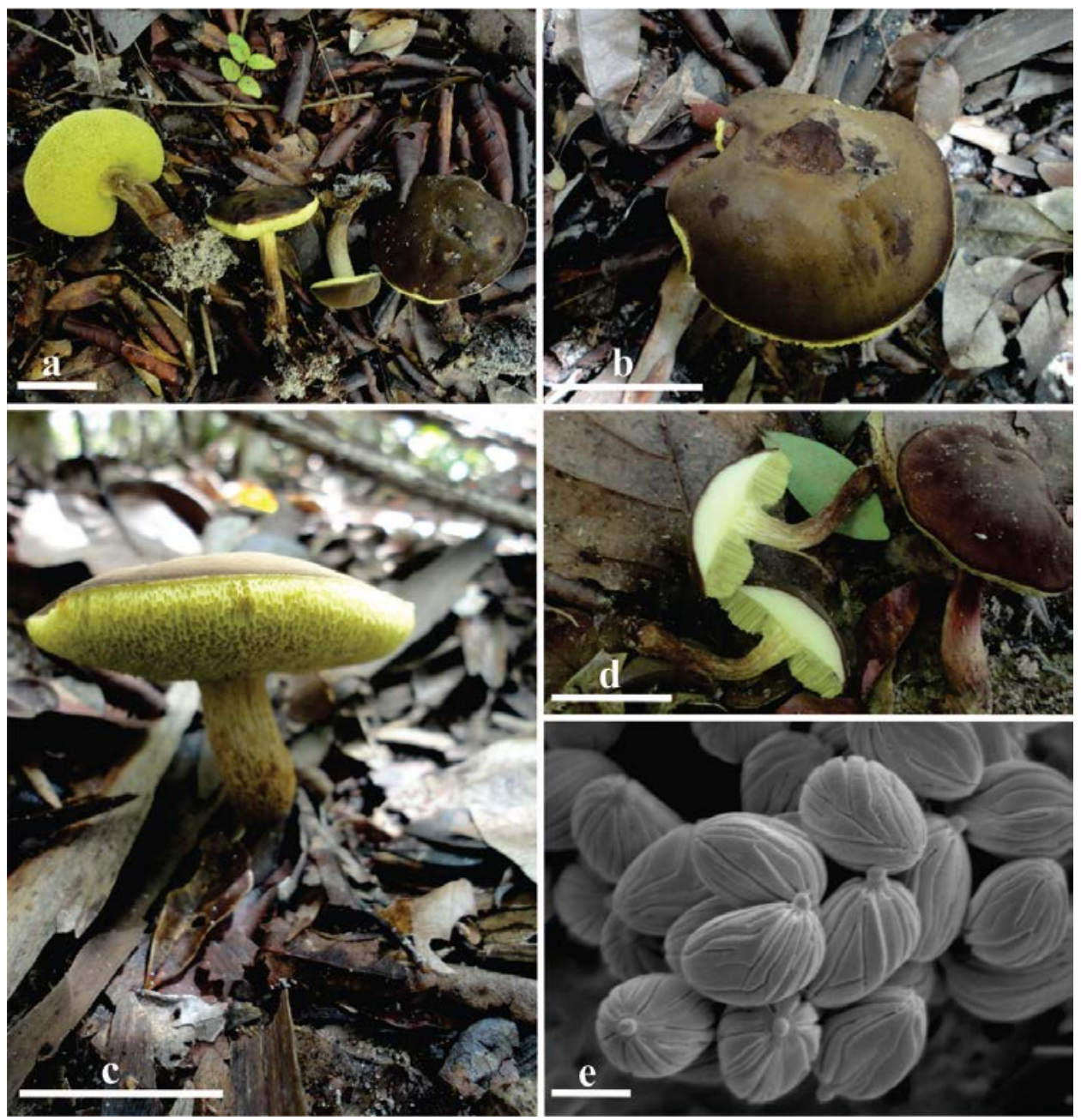

Fig. 2 - Macromorphology in the field and SEM of the basidiospores of Boletellus nordestinus. a Voucher UFRN-Fungos2721 (holotype). b Detail of pileus surface (UFRN-Fungo 2725). c Detail of the hymenophore (UFRN-Fungos 2725). d Basidiomata in cross section (UFRN-Fungo 2729) (Scale Bar: 3 cm). e SEM micrograph of basidiospores (FLOR51604). Scale Bars: $5 \mu \mathrm{m}$. 


\section{Acknowledgements}

A.C. Magnago thanks the Conselho Nacional de Desenvolvimento Científico e Tecnológico (Cnpq) for the fellowship and Cnpq-Processo 457489/2014-6 (Projeto Universal) provided funding to M.A. Neves. Reserva Biológica Guaribas and Parque Estadual Dunas de Natal for research permits and support during fieldwork. We thanks Eduardo P. Fazolino for providing collections from Rio Grande do Norte and Genivaldo Alves-Silva for helping in the molecular procedures.

\section{References}

Baltazar JM, Ryvarden L, Gilbertoni TB. 2010 - The genus Coltricia in Brazil: new records and two new species. Mycologia 102, 1253-1262.

Barbosa-Silva A, Ovrebo CL, Ortiz-Santana B, Sá MCA et al. 2017 - Tylopilus aquarius, comb. et stat. nov., and its new variety from Brazil. Sydowia 69, 115-122.

Barbosa-Silva A, Wartchow F. 2017 - Studies on Boletellus sect. Boletellus in Brazil and Guyana. Current Research in Environmental \& Applied Mycology 7, 387-395.

Corner EJH. 1972 - Boletus in Malaysia. Government Printing Office. Singapore, 1-263.

Dentinger BTM, Margaritescu S, Moncalvo JM. 2010 - Rapid and reliable high-throughput methods of DNA extraction for use in barcoding and molecular systematics of mushrooms. Molecular Ecology Resources 10, 628-633.

Doyle JJ, Doyle JL. 1987 - A rapid DNA isolation procedure for small quantities of fresh leaf tissue. Phytochemical Bulletin 19,11-15.

Freire MSB. 1990 - Levantamento florístico do Parque Estadual das Dunas do Natal. Acta Botanica Brasilica 4, 41- 69.

Fulgenzi TD, Mayor JR, Henkel1 TW, Halling RE. 2008 - New species of Boletellus from Guyana. Mycologia 100, 490-495.

Gilbert EJ. 1931 - Les Livres du Mycologue Tome III: Les Bolets.

Góes-Neto A, Loguercio-Leite C, Guerrero RT. 2005 - DNA extraction from frozen field-collected and dehydrated herbarium fungal basidiomata: performance of SDS and CTAB-based methods. Biotemas 18, 19-32.

Gómez LD. 1996 - Basidiomicetes de Costa Rica: Xerocomus, Chalciporus, Pulveroboletus, Boletellus, Xanthoconium (Agaricales, Boletaceae). Revista de Biologia Tropical 44, 59-89.

Halling RE, Mueller GM. 2005 - Common Mushrooms of the Talamanca Mountains, Costa Rica. New York: New York Botanical Gardens Press.

Halling RE, Ortiz-Santana B. 2009 - A revision of Boletellus sect. Ixocephali. Mycological Progress 8, 237-244.

Halling RE, Fechner N, Nuhn M, Osmundson T et al. 2015 - Evolutionary relationships of Heimioporus and Boletellus (Boletales), with an emphasis on Australian taxa including new species and new combinations in Aureoboletus, Hemileccinum and Xerocomus. Australian Systematic Botany 28, 1-22.

Heinemann P, Goossens-Fontana M. 1954 - Flore iconographique des champignons du Congo. In: Fascicle 3. Boletineae. Brussels: Le Jardin Botanique de l'Etat. 1-34.

Horak E. 1977 - Boletellus and Porphyrellus in Papua New Guinea. Kew Bulletin Add. Series 31, 645-652.

Kearse M, Moir R, Wilson A, Stones-Havas S et al. 2012 - Geneious Basic: an integrated and extendable desktop software platform for the organization and analysis of sequence data. Bioinformatics 28, 1647-1649.

Kramer LA. 2004 - The Online Auction Color Chart. Online Auction Color Chart Company, Stanford, 1-12.

Largent DL, Johnson D, Watling R. 1977 - How to identify mushrooms to genus III: microscopic features. 3 edn Eureka, California: Mad River Press Inc. 1-148.

Magnago AC, Neves MA. 2014 - New record of Austroboletus festivus (Boletaceae) from Santa Catarina, Brazil. Brazilian Journal of Botany 37, 197-199. 
Magnago AC, Neves MA, Silveira RMB. 2017a - Fistulinella ruschii sp. nov., and a new record of Fistulinella campinaranae var. scrobiculata for the Atlantic Forest, Brazil. Mycologia

Magnago AC, Reck MA, Dentinger BTM, Moncalvo JM et al. 2017b - Two new Tylopilus species (Boletaceae) from northeastern Atlantic Forest, Brazil. Phytotaxa 316, 250-260.

Magnago AC, Henkel T, Neves MA, Silveira RMB. 2018a - Singerocomus atlanticus sp. nov., and a first record of Singerocomus rubriflavus (Boletaceae, Boletales) for Brazil. Acta Botanica Brasilica 32, 222-231.

Magnago AC, Alves-Silva G, Neves MA, Silveira RMB. 2018b - A new species of Gyroporus (Gyroporaceae, Boletales) from Atlantic Forest in Southern Brazil. Nova Hedwigia 107, 291301.

Murrill WA. 1909 - The Boletaceae of North America. Mycologia 1, 4-18.

Nuhn ME, Binder M, Taylor AFS, Halling RE, Hibbett DS. - 2013 - Phylogenetic overview of the Boletineae. Fungal Biology 117, 479-511.

Oliveira IC, Sousa MA. 1995 - Boletales (Hymenomycetes) no Campus I da Universidade Federal da Paraíba, João Pessoa: I - Xerocomaceae. Revista Nordestina de Biologia 10, 85-99.

Ortiz-Santana B, Lodge DJ, Baroni TJ, Both EE. 2007 - Boletes from Belize and the Dominican Republic. Fungal Diversity 27, 247-416.

Sá MCA, Wartchow F, Baseia IG. 2013 - Lactifluus dunensis, a new species from Rio Grande do Norte, Brazil. Mycosphere 4, 261-265.

Sato H, Hattori T. 2015 - New species of Boletellus section Boletellus (Boletaceae, Boletales) from Japan, B. aurocontextus sp. nov. and B. areolatus sp. nov. PloS ONE 10(6), e0128184.

Singer R. 1970 - Strobilomycetaceae (Basidiomycetes). Flora Neotropica Monograph 5, 1-34.

Singer R. 1986 - The Agaricales in Modern Taxonomy. 4 edn. Koeltz Scientific Books, Koenigstein.

Singer R, Araujo I, Ivory MH. 1983 - The ectotrophically mycorrhizal fungi of the neotropical lowlands, especially central Amazonia. Beihefte zur Nova Hedwigia 77, 1-352.

Singer R, Garcia J, Gómez LD. 1992 - The Boletineae of Mexico and Central America IV. Beihefte zur Nova Hedwigia 105, 1-62.

Smith H, Thiers HD. 1971 - The Boletes of Michigan. The University of Michigan Press.

Snell WH, Dick EA. 1970 - The Boleti of Northeastern North America. Lehre, Germany: J. Cramer.

Sulzbacher MA, Giachini AJ, Grebenc T, Silva BDB et al. 2013 - A survey of an ectotrophic sand dune forest in the northeast Brazil. Mycosphere 4, 1106-1116.

Tedersoo L, May TW, Smith ME. 2010 - Ectomycorrhizal lifestyle in fungi: global diversity, distribution, and evolution of phylogenetic lineages. Mycorrhiza 20, 217-63.

Vilgalys R, Hester M. 1990 - Rapid genetic identification and mapping of enzymatically amplified ribosomal DNA from several species of Cryptococcus. Journal of Bacteriology 172, 42384246.

Wu G, Feng B, Xu J, Zhu XT et al. 2014 - Molecular phylogenetic analyses redefine seven major clades and reveal 22 new generic clades in the fungal family Boletaceae. Fungal Diversity 69, 93-115.

Wartchow F, Bezerra JL, Cavalcanti MAQ. 2013 - Lactifluus batistae (Russulaceae), a new species from Bahia, Brazil. Agrotrópica 25, 103-108.

Watling R. 2001 - Australian boletes: their diversity and possible origins. Australian Systematic Botany 14, 407-16. 